Article

\title{
Sustainable Mobility at Thirty
}

\author{
Erling Holden ${ }^{1}$, Geoffrey Gilpin ${ }^{1, *}$ and David Banister ${ }^{2}$ \\ 1 Faculty of Engineering and Sciences, Western Norway University of Applied Sciences, 5020 Bergen, Norway; \\ erling.holden@hvl.no \\ 2 Transport Studies Unit, School of Geography and the Environment, University of Oxford, \\ Oxford OX1 3QY, UK; david.banister@ouce.ox.ac.uk \\ * Correspondence: geoffrey.sean.gilpin@hvl.no; Tel.: +47-99-52-11-06
}

Received: 14 March 2019; Accepted: 27 March 2019; Published: 2 April 2019

\begin{abstract}
It is now almost three decades since the concept of 'sustainable mobility' first appeared in the 1992 EU Green Paper on the Impact of Transport on the Environment. This paper reviews the literature and reflects on how societies' understanding and interpretation of the concept of sustainable mobility has evolved. We track this evolution over six dimensions: research and policy, transport impacts and categories, scientific disciplines, methodological approach, and research questions. From this review we assert that the mainstream understanding and interpretation of sustainable mobility can be grouped into four generations of studies. The first generation of studies (1992-1993) were techno-centric and focused on how to limit transport's negative environmental impacts by improving then-existing technology. The second, third and fourth generations of studies (1993-2000, 2000-2010 and 2010-2018 respectively) increasingly acknowledge the limitations of preceding efforts to achieve sustainable mobility, and open for a more diverse set of alternatives. These studies have gradually become more interdisciplinary in nature-reflecting the inter-relatedness of mobility with all other aspects of society. We conclude that despite the ensuing elevation of mobility into the holistic picture society, we still have not achieved a sustainable mobility system. Furthermore, what is much needed now, more than ever, is a bold set of new narratives.
\end{abstract}

Keywords: sustainable mobility; concept evolution; generations; policy

\section{Introduction}

"This Green Paper provides an assessment of the overall impact of transport on the environment and presents a Common strategy for 'sustainable mobility' which should enable transport to fulfil its economic and social role while containing its harmful effects on the environment" [1] (p. 5).

This quote is from the $1992 \mathrm{EU}$ Green Paper on the Impact of Transport on the Environment [1]. The paper was a direct European Union (EU) response to the challenges raised a few years earlier by the United Nations (UN) report, Our Common Future [2]. It was a clear statement of transport policy in the EU, and it focused on the rapidly increasing environmental impacts from the transport sector. It was the first time the concept of 'sustainable mobility' appeared on the international agenda-a bold but much needed appearance. The Green Paper covered issues of environmental protection, safety and security, consumer protection, labour rights and social policy, and the external costs of transport were made explicit, but little was said about climate change. Nevertheless, it was still bold through its consideration of the intertwined and exceedingly complex relationship between transport's positive effects and its negative social and environmental impacts. It has proved difficult to find a comfortable match between transport and sustainable development. It was much needed as it was widely acknowledged that we must address the increasingly devastating impacts of transport because the overall negative impacts were beginning to exceed the overall positive ones, that is, business-asusual was unacceptable. 
Almost three decades after Our Common Future and the Green Paper, the UN presented the 2030 Agenda for Sustainable Development comprising 17 sustainable development goals (SDGs) and 169 targets [3]. This, too, was another bold step, but the apparent absence of transport and its impacts in this document is striking as well as alarming. Admittedly, the 2030 Agenda enthusiastically states that 'we will adopt policies which increase [ ... ] sustainable transport systems ... ' [3] (p. 8)—but how helpful is this? SDG target 11.2 proves to be a little more helpful stating: 'By 2030, provide access to safe, affordable, accessible and sustainable transport systems for all, improving road safety, notably by expanding public transport, with special attention to the needs of those in vulnerable situations, women, children, persons with disabilities and older persons' [3] (p. 21). Thus, the SDG targets are diffuse and set at a very general level regarding transport, making it difficult to draw clear conclusions as to whether progress is being made towards target achievement.

It seems strange that the 2030 Agenda apparently neglects the negative impacts of the transport sector. At present, the transport sector consumes approximately one-third of our final energy and probably causes more environmental and social problems than any other sector (we will return to these problems in the next section). This paper provides a response to this neglect and an attempt to put sustainable mobility where it belongs, that is, at the top of the sustainable-challenges podium.

At this point, four clarifications seem necessary-two are conceptual and two are practical. First, some scholars argue that there is a difference between the terms sustainable development and sustainability-for example, that sustainable development ultimately gives priority to development and that sustainability is primarily about the environment, (e.g., [4]), or that sustainability refers to a goal whereas sustainable development refers to the process that leads us to sustainability (e.g., [5]). To us, these two terms express the same idea and the same policy implications. Thus, we use them interchangeably.

Second, in the literature on transport and sustainable development, the terms "sustainable transport" (also sustainable transportation and sustainable transport systems etc.) and "sustainable mobility" are used synonymously [6]. Sustainable transport seems to be preferred in North America, and sustainable mobility in Europe [7]. We consider that both terms embody the concept of mobility [8], i.e., revealed mobility (actual, physical displacement) and potential mobility (attribute of being mobile). Furthermore, they entail the same ideas and policy implications, thus, we use them interchangeably.

Third, we focus on passenger mobility in developed countries (particularly the EU). The equally important challenges of achieving sustainable goods transport and achieving sustainable mobility in developing countries should not be forgotten. The conclusions reached here should, however, be transferable to the freight sector, and generally applicable to developing countries.

Fourth, we focus on sustainable mobility's environmental imperative because this is the developed countries' main challenge towards achieving sustainable mobility [9]. The equally important imperatives of transport-needs and equal access to transport should not, however, be forgotten [10].

Having said this, the challenges and literature review presented here should be relevant for studying how to achieve sustainable goods transport and, moreover, achieving sustainable mobility in developing countries.

The paper proceeds as follows: Section 2 presents how motorized passenger transport has increased during the last century, and it highlights the negative social and environmental impacts resulting from this increase. Section 3 presents a literature review of the mainstream understanding and interpretation of sustainable mobility studies over the last three decades. Finally, we summarize in Section 4.

\section{A Hundredfold Increase in a Hundred Years}

Travel has been part of the human experience since the migrations out of Africa millions of years ago. People's motivation for travelling has varied, though for the most part, people have travelled to improve their lives. Whatever their motivation, travel in early times was uncomfortable, dangerous and enormously time-consuming-today, some might argue that little has changed; travel is still 
uncomfortable, dangerous and enormously time-consuming. There are, however, two indisputable differences between travel then and now: in modern times there has been an extraordinary growth in mobility (in terms of trips made and distance travelled by motorized passenger kilometres) and a great increase in its environmental and social consequences.

During the twentieth century, growth-rates in population were remarkable-with the world's population growing by a factor of about four. The growth in mobility was remarkable too-with motorized passenger kilometres and tonne-kilometres by all modes growing on average by a factor of about 100 [11] (e.g., Figure 1). However, whereas population growth shows signs of levelling-off, the growth in mobility does not. In particular, the growth in mobility has been extensive during the last half century. For example, in 1952, the average Norwegian travelled $5.5 \mathrm{~km}$ daily by motorized means. By 2000 this figure had increased to $48.7 \mathrm{~km}$ daily [12]. This growth has continued steadily into this century [13]. A similar pattern can be found in the EU and all other Organisation for Economic Co-operation and Development (OECD) countries (There was a temporarily decline in transport volumes during the global financial crises between 2007 and 2011. From 2012 on, however, transport has increased.) $[14,15]$. Furthermore, comparisons of global scale baseline (business-as-usual) scenarios foresee that this trend, particularly of increased travel by road-freight and air, are likely to increase by 2050 [16].

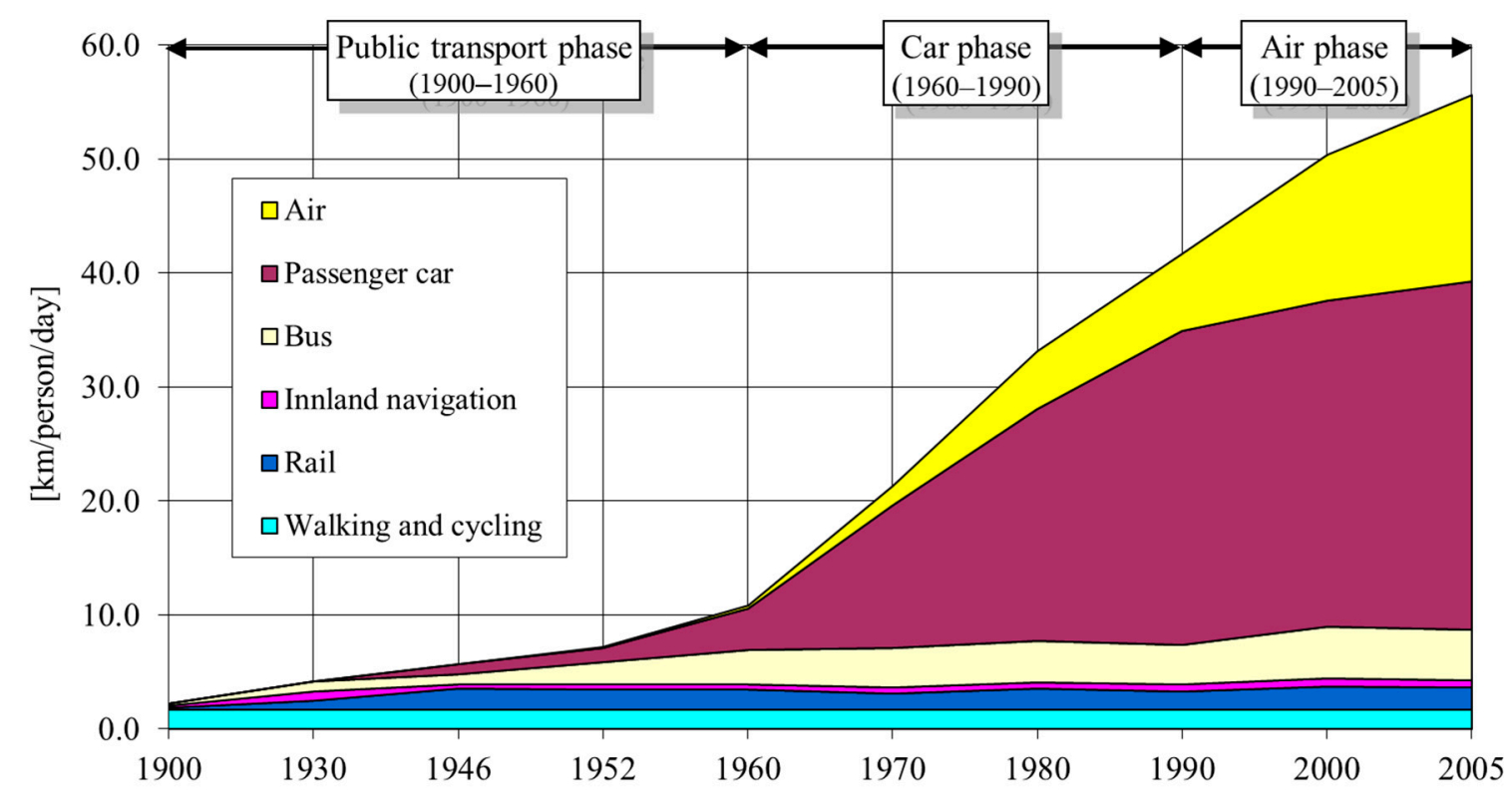

Figure 1. Passenger transport in Norway 1900-2005. [12].

While transport and mobility are widely acknowledged as important elements in economic growth and accessibility, and integral towards the achievement of sustainable development [17], the negative social and environmental impacts of increased motorized mobility-in particular road and air travel—have been broadly acknowledged:

- Transport is a major consumer of energy and material resources. Around 31.6\% (2016) of the world's final energy consumption is used for transport, mostly from non-renewable energy resources [18].

- The production of motor vehicles requires large amounts of materials, e.g., ferrous and non-ferrous metals. Currently (2017) motor vehicle production consumes $7 \%$ and $3 \%$ of ferrous metals (similar for non-ferrous) in OECD and non-OECD countries respectively. Demand for metals in these regions is expected to grow by a factor of 2.2 and 3.5, respectively, between 2017 and 2060 [19].

- Transport is a major contributor to local, regional and global pollution of the air, soil and water. For example, transport is currently (2016) the source of $24 \%$ of global $\mathrm{CO}_{2}$ emissions [20]. 
- While transport networks and infrastructures cover only $3 \%$ of artificial land in Europe [21], the associated impacts can have dire consequences, e.g., land fragmentation which in turn effects biodiversity.

- About 1.35 million people worldwide are killed in road traffic crashes, costing most countries 3\% of their Gross Domestic Product (GDP) [22].

- Access to mobility services has been uneven, resulting in more unequal access to public and private services and instances of social exclusion [23-26].

These observations have led to the diagnosis of an unsustainable mobility system [27-31], and without major changes in policies and practices, the unsustainability of the transport system will continue well towards the end of this century-but why is this so?

The long-term and complex nature of the transport system makes mobility patterns difficult to influence [32]. The long-term nature reflects the fact that many of the investments in transport influence mobility patterns for a very long time. Roads, bridges and airports have a very long life and continue to influence how we travel for a good part of a century. Cars, trains and planes all have a long life and a turnover of a fleet take decades. Thus, changing the transport system and subsequently mobility patterns is a long-term process.

The complexity of the transport system comes from the fact that it consists of three interconnected sub-systems. The first sub-system covers the motorized means of transport. Here, sustainable mobility requires an assessment of both the technological development of the means of transport and the total distance travelled by each mode. Thus, sustainability claims are not limited to artefacts such as vehicles but pertain to the level of mobility in society. The second sub-system is the transport infrastructure. Here, sustainable mobility requires an assessment of all relevant impacts during construction, use, maintenance and decommissioning for each mode of transport, including the energy and resources embedded in the infrastructure itself (such as concrete, asphalt and control systems). The third sub-system is the energy system, including the energy carriers used to power the various means of transport. Here, sustainable mobility requires a comparative appraisal of both conventional energy systems, including possible improvements and alternative energy systems-including both the provision and use of transport and energy facilities (infrastructure).

There are several agents operating in and across the transport system and its sub-systems. These are governments (at different levels), firms, and the people. Moreover, there are several strategies that can be applied to achieve sustainable mobility, such as to increase efficiency, to facilitate mode shifts, and to enable reduction in the number of trips and trip lengths. Several sustainable mobility narratives derive from combinations of agents and strategies. A sustainable mobility narrative is a story comprising a set of actions (initiated by agents) of how we should proceed (applying strategies) to achieve sustainable mobility. We argue that we more than ever need such narratives that governments, firms and the people find understandable, attractive and motivational so they can believe in them and subsequently support (See Holden et al., forthcoming).

As such, an assessment of the sustainability of a transport system requires a long-term integrated assessment of positive and negative impacts of all three sub-systems. How has the academic literature on sustainable mobility responded to this requirement? In the next section, we will present a review of this literature starting from the 1992 launch of the sustainable mobility concept. We show that the literature has evolved gradually to address the broadening requirements presented above.

\section{A Review of the Sustainable Mobility Literature}

This review focuses on studies which deal explicitly with sustainable mobility, and this means that the review represents first-level theorizing on sustainable mobility. There exists a plethora of studies which do not explicitly deal with sustainable mobility, but that nevertheless deal with certain important aspects of it. These studies, which include discipline-specific studies within technology-orientated environmental studies, sociology, psychology and planning research, represent second-level theorizing on sustainable mobility. It should be mentioned, however, that no sharp distinction exists between 
studies in the first-level presented here, and studies in the second-level. Indeed, they all belong to the wider interdisciplinary discourse on sustainable mobility.

Since the EU introduced the concept of sustainable mobility in its 1992 Green Paper on Transport [1], there has been a steady increase in the number of books, articles and reports about sustainable mobility in line with the increasing unsustainability of the transport sector. There now is a large and rich literature covering this field, and since most projections forecast that transport will continue to grow more unsustainable over the coming years, the number of books, articles and reports is likely to increase too.

In an earlier study, Holden [6] presented a review of the sustainable mobility literature between 1992 and 2005. The review presented here (from now on referred to as 'Review') draws on the earlier study but update it to include the literature between 2005 and 2018.

This Review shows clearly that mainstream interpretations of the concepts "sustainability" and "mobility" are different today from what they were almost three decades ago. Moreover, current literature draws on more scientific disciplines than the early literature did. Surely, there have always been some studies that deviated from the mainstream studies. Nevertheless, this Review gives a strong indication of how the typical understanding and interpretation of the sustainable mobility concept have changed since the early 1990s.

Furthermore, we can draw two important lessons which have contributed to changing our perception of the concept of sustainable mobility since 1992. First, this Review shows that there are six dimensions by which sustainable mobility can be typically understood: research and policy focus, transport's impacts (that is the interpretation of sustainability), travel categories (that is the interpretation of mobility), scientific disciplines, methodological approaches, and types of research questions (We have used thematic analysis $[33,34]$ to find sustainable mobility's main dimensions (which are six), and how the typical understanding and interpretation of these dimensions have changed over time into generations (which are four). Sustainable mobility studies were collected through the EU (policy documents), ScienceDirect.com (scientific articles) and Amazon.com (academic books). Information from these studies were codified and subsequently formed themes across space (dimensions) and time (generations)).

Second, this Review shows that the typical understanding and interpretation of sustainable mobility can be clustered into four generations: the first generation (1992-1993), the second generation (1993-2000), the third generation (2000-2010), and the fourth generation (2010-2018) (First generation: e.g., [1,35-40]. Second generation: e.g., [36,41-52]. Third generation: e.g., [7,25,27,48,53-66]. Fourth generation: see text.). Between these generations, changes have occurred in our understanding and interpretation of the concept of sustainable mobility, which are explained in the following sections and depicted in Table 1.

\subsection{Research and Policy Focus}

Changes in the mainstream studies' understanding and interpretation of the concept occurred in the policy-focus dimension. Our Common Future's recommendation for a reduction in per capita energy consumption translated into an emphasis on reduced transport volume in the 1992 EU Green Paper [1]. Furthermore, in the early 1990s, some EU countries supported not only a general reduction in consumption, but in particular a reduction in transport. However, already by 1993, EU transport policy represented a change in focus from one that recommended a reduction in overall transport volume - to curb global resource consumption and pollution-to one that recommended a reduction in transport intensity. Whereas the focus on transport volume addressed overall travel distances $(\mathrm{km})$, fuel consumption (liter) and global emissions (tons, particularly $\mathrm{CO}_{2}$ ), the focus on transport intensity addressed specific fuel consumption (liter per $\mathrm{km}$ ) and local emission (grams per kilometer) [41]. The former implies travel less, the latter implies travel more efficiently. 
Table 1. Four generations of studies on sustainable mobility (modified and updated version of Holden [6]).

\begin{tabular}{|c|c|c|c|c|}
\hline Dimension & First Generation [1992-1993] & $\begin{array}{c}\text { Second Generation } \\
\text { [1993-2000] }\end{array}$ & Third Generation [2000-2010] & Fourth Generation [2010-2018] \\
\hline $\begin{array}{l}\text { Research and (EU) } \\
\text { policy focus }\end{array}$ & limit transport volume & Reduction in transport intensity & + congestion, equity, competitiveness & + decarbonisation \\
\hline $\begin{array}{l}\text { Transport's impacts } \\
\text { (i.e., sustainability) }\end{array}$ & environmental impact & $\begin{array}{l}\text { + societal impact } \\
\text { (Quality of life) }\end{array}$ & $\begin{array}{c}\text { + economic impact, accessibility, } \\
\text { distribution }\end{array}$ & all dimensions of sustainability \\
\hline $\begin{array}{l}\text { Travel categories } \\
\text { (i.e., mobility) }\end{array}$ & production travel (work) & $\begin{array}{l}\text { + reproduction travel } \\
\text { (non-work travel by car) }\end{array}$ & $\begin{array}{l}\text { + leisure-time travel (including } \\
\text { long-distance travel by car and plane) }\end{array}$ & $\begin{array}{l}\text { + shared mobility, autonomous driving } \\
\text { and electromobility }\end{array}$ \\
\hline Scientific disciplines & $\begin{array}{l}\text { environmental engineering, } \\
\text { planning, transport geography, } \\
\text { transport economy }\end{array}$ & + sociology & $\begin{array}{l}\text { + psychology, social psychology, } \\
\text { anthropology, political science, history, } \\
\text { public health (interdisciplinary) }\end{array}$ & $\begin{array}{l}\text { + innovation studies, sustainability } \\
\text { transitions }\end{array}$ \\
\hline $\begin{array}{l}\text { Methodological } \\
\text { approaches [and } \\
\text { theories] }\end{array}$ & $\begin{array}{c}\text { environmental impact } \\
\text { assessment, quantitative } \\
\text { modelling, regression analysis }\end{array}$ & $\begin{array}{l}\text { + qualitative analysis (scenario } \\
\text { building, scenario analysis?) }\end{array}$ & $\begin{array}{l}\text { + case studies, in-depth interviews, } \\
\text { qualitative modelling, institutional } \\
\text { analysis, historical interpretive analysis }\end{array}$ & $\begin{array}{l}\text { + Multilevel Perspective (MLP), } \\
\text { Technological Innovation Systems (TIS), } \\
\text { big data }\end{array}$ \\
\hline $\begin{array}{l}\text { Types of research } \\
\text { questions }\end{array}$ & $\begin{array}{l}\text { How to increase the efficiency } \\
\text { of different modes of transport? }\end{array}$ & $\begin{array}{l}+ \text { How to manage traffic } \\
\text { demand? }\end{array}$ & $\begin{array}{l}\text { + What are the different actors' } \\
\text { motivation, opportunities, and abilities } \\
\text { to change? }\end{array}$ & $\begin{array}{l}\text { + How to create synergies between } \\
\text { environmental effects and the wider social } \\
\text { implications on health and inequality? }\end{array}$ \\
\hline
\end{tabular}

' + ' indicates that the focus of the previous generation is broadened to include the marked item. 
In the succeeding decade, the emphasis on reduced transport volumes became of secondary importance. Indeed, by 2001, the EU White Paper on European Transport Policy [44] did not support the idea of reduced transport volume, indicating that apparently the EU neither had the means nor the desire to support a reduction in transport. Moreover, between 2000 and 2010, there has been an increased focus on reduced local pollution was accompanied by calls for reduced congestion, increased competitiveness and improved quality of life-all of which have taken precedence [44].

The 2011 White Paper acknowledged that 'still, the transport system is not sustainable' [67] (p. 4). However, the White Paper had no intention of picking up the transport-volume debate, and in order to leave no doubt stated that 'curbing mobility is not an option' [67] (p. 5). Instead, the White Paper spurred a fourth generation of policy's understanding of sustainable mobility where the main focuses were on oil-independency and the $2{ }^{\circ} \mathrm{C}$ climate target. Luck has it that both focuses call for a common strategy, that is, de-carbonization. In 2017, the Commission identified several de-carbonization strategies, such as cooperative, connected and automated transport; transport electrification (electromobility); vehicle design and manufacturing; low-emission alternative energy for transport; network and traffic management systems; smart mobility and services; and infrastructure [68].

Research priorities were also changed as a symbiosis exists between research and policy. On one hand, research influences policy by providing knowledge of the efficiency and impact of various policies to politicians and bureaucrats. On the other hand, policy (including R\&D policy) influences research by providing a frame-important issues and funding-for the research community. Thus, the focus of a transport policy has corresponded to the focus in mainstream transport research.

\subsection{Transport Impacts}

During this period, there were also changes in the dimension concerning transport's impacts. Whereas most studies of sustainable mobility carried out in the early 1990s focused predominantly on environmental impacts, this was eventually broadened to include societal impacts. By the time of the early 2000s, wider economic impacts were added to transport assessment, such as accessibility and distribution. Thus, the mainstream studies on sustainable mobility now focus on the broad environmental, societal, and economic impacts. Thus, the concept of sustainable mobility has slowly developed from one entailing concerns over individual environmental issues to one that acknowledges the widening of issues concerning sustainable development [69].

\subsection{Travel Categories}

Changes have also taken place in the dimension of travel categories. Vilhelmson [70] distinguishes between three categories of travel: production travel (travel to work and school), reproduction travel (travel to shop and nursery school) and leisure-time travel (travel to recreational activities, on holidays and to visit friends and relatives). Whereas most sustainable mobility studies in the early 1990s assessed only the impacts of production travel, studies in the late 1990s also assessed the impacts of reproduction travel. After 2000, studies began assessing the impacts of the staggering growth in leisure-time travel by car and plane. In summary, the focus of sustainable mobility research evolved as follows: the first generation was primarily on production travel, the second generation was broadened to include reproduction travel and finally the third generation was broadened further to include leisure-time travel. Though not categorized as travel categories per se, the fourth generation of sustainable mobility studies includes three new developments relevant for this dimension, i.e., shared mobility [71,72], autonomous vehicles [73-76], and electromobility $[77,78]$.

\subsection{Scientific Disciplines}

Additional changes occurred in the dimension of scientific disciplines. Since 2000, research on sustainable mobility has gradually included new disciplines and is today becoming more interdisciplinary. This is quite different from the situation three decades ago when transport engineers, planners, transport geographers and transport economists dominated the field. During the 1990s, 
several sociological studies were carried out, and from 2000 the sociological studies were accompanied by public health researchers, historical, political scientific, psychological and anthropological studies.

After 2010, we have seen a strong increase in innovation studies [79] and sustainability transitions studies [80]. These studies do not represent distinct disciplines by themselves, but draw on a wide range of scientific disciplines, such as management studies, sociology, political sciences, natural sciences, engineering, economic geography and economics. Innovation and transition studies draw on many of the same disciplines, but innovation studies typically draw on a wider spectre of disciplines than transition studies do. Though most sustainable transition studies focus on energy and climate issues, a significant proportion focus on transport issues (e.g., [81-85]).

\subsection{Methodological Approaches and Theories}

Studies in the early years were mainly based on environmental impact assessments, quantitative modelling and regression analysis. During the early intermediate years, studies based on scenario building and scenario analysis grew in popularity. When sociologists, psychologists and others fully entered the sustainable mobility research field around 2000, a broad spectrum of scientific methods began being used, such as case studies, in-depth interviews, qualitative modelling, institutional analyses and historical interpretive analysis. Each of the disciplines included in the three first generations of sustainable mobility brought their own theories too numerous to present here.

The fourth generation of studies applies many of the same methodological approaches as the previous generations. They brought, however, an enormous amount of new theories into the sustainable mobility domain (see [86] for an overview). Within system innovation and transition studies, four theoretical frameworks have achieved quite some prominence [80], these include transition management (e.g., [87]), strategic niche management (e.g., [88]), the multi-level perspective on sociotechnical transitions (e.g., [89]), and technological innovation systems (e.g., [90]). Also, access to a range of new data sources, advanced data mining techniques and the use of big data, now makes it possible to conduct richer and deeper sustainability analyses of the inherently complex and long-term nature of the transport system.

\subsection{Research Questions}

Over time, the types of research questions being addressed have changed, from being relatively simple to being much more aware of the many different interrelated components of a sustainable transport system. Indeed, it has become increasingly apparent that the problem is not only a transport one, but one that also relates to urban form, decisions on the location of housing and everyday facilities, the changing requirements of society, and the means by which social media and the internet can impact on activity patterns. In 1992-1993, questions were asked about the efficiency of different modes of transport, looking towards 'greening' existing modes through greater fuel efficiency and through reductions in emissions. It should be remembered at this time that the debates over global warming were only just beginning. The expectation here was that transport systems could become more efficient without any real change in the modal split or in the desired travel patterns. There was little more fundamental discussion about the nature and scale of the problem, only that small changes would allow a continuation of the increasing demand for travel, and that additional capacity would be provided to meet that demand-this was part of the dominant narrative of predict and provide.

In about 1993 it was recognised by governments that transport was not sustainable and that a different approach was needed that gave a much greater priority to public transport (particularly in cities), as this was seen as the best means to carry large numbers of people around efficiently. The car was still given great freedom, but there were now constraints such as parking limitations and charges being imposed, sometimes justified by environmental reasons. This approach was seen to be more 'balanced' as the case was made that the car had to adapt to the city and that the city could no longer cope with the congestion that resulted from the continued growth in car use. It was also realised that there were strong social and environmental arguments to limit the use of the car. In addition to the 
promotion of public transport, this was the period during which more efficient technology was being introduced to manage traffic demand (e.g., traffic control systems, traffic free central areas, access control). Land-use planning was now addressing the means to reduce trip lengths through the closer integration of services and facilities, and decisions on where new housing was to be built took greater account of the available transport system. The complexity of the transport and land use interactions was beginning to be understood, and that a sustainable transport system could not be provided by just concentrating on greater efficiency within transport.

At the beginning of this century, it seemed to be accepted that the transport system was unsustainable and that the trends were all in the wrong direction. The situation was getting worse and not better. Many of the approaches and means to make transport more sustainable were now well understood, and the problem was how to implement effective changes to reduce car use in cities. The solutions moved from being the primary responsibility of the expert to that of a much wider range of actors, including politicians, businesses, investors and the public. Understandably, communication and acceptability all became central issues in the debate over sustainable transport. There was a need for in-depth knowledge concerning the different actors' motivation, opportunities and abilities to change, and this in turn substantially widened the discussions and the range of different scientific and social scientific disciplines involved in promoting sustainable transport. The field had now become truly interdisciplinary.

The current situation has become more complex and interesting, with new arguments being used over sustainable transport that relate not just to the health of the environment, but to the health of people as the quality of the local environment has become a central element in the debate. This covers the promotion of healthy forms of transport (walk and cycling) as well as an increasing concern over the indirect effects of pollution from motorised vehicles on local air quality and health, in particular for the more vulnerable people in society (e.g., the young and the elderly) [91]. In the past, the main arguments over transport has been the extent to which it has sustained economic growth by allowing for the more efficient movement of people and goods. Now, the arguments have moved towards addressing the wider concepts of sustainability that cover the environmental effects (both global and local) and the wider social implications on health and inequality [92].

The solutions being sought now and into the future are also much more imaginative, as they cover the actions that individuals can take to maintain an active lifestyle, to use local services and facilities, and to promote local environmental quality (e.g., green and open space). Actions also concern employers, schools, hospitals and other major employers so that they can take a greater responsibility to encourage the use of sustainable transport modes, and for city planners to design sustainability into urban form. Technology also has an increasing role to play with private investors committing substantial funds to research and development into autonomous vehicles, electric vehicles, mobility apps, information and guidance systems, and the means by which the need to travel can be reduced. The opportunities are now here for a real revolution in transport to take place that might lead to the current unsustainable forms of transport being made sustainable.

All measures should be applied in mutually supporting ways so that sustainable mobility can be achieved. It is no longer a question of alternatives, but one of making the best use of all available technologies, planning decisions, lifestyles and behavioural changes, together with fully supportive political, legislative and regulatory regimes.

\section{Summary}

Three decades ago, the EU Green Paper on the Impact of Transport on the Environment [1] raised serious concerns about the negative impacts of transport. The Green Paper clearly identified 'transport as a major contributor to energy and environmental problems since it is one of the main consumers of fossil fuels and it is responsible for considerable nuisance and damage to the environment' [1] (p. 2). In summary, they described an unsustainable mobility system. The Green Paper did not avoid confrontation, as it was argued that we need to go 'to go to the very root of the problem—human behaviour', and that doing so 
requires 'fundamental changes in human values towards the environment and in patterns of behaviour and consumption'. Moreover, they argued for 'promoting fast, safe, and convenient urban and regional transport services and reducing urban car traffic', and they were even bold enough to suggest 'the need to encourage low transport demand' [1] (p. 1).

Now, almost three decades later, the mainstream understanding and interpretation of this fundamental concept has changed. Neither sustainable mobility as a concept nor its connotations-as they have evolved in the six proposed dimensions, over four generations-are as bold as they once were. This is both due to an increased familiarity resulting from the passage of time, but also its evolution has blurred our perceptions. All six dimensions have individually experienced a broadening of: formulation, impacts, categories, disciplines, approaches and theories, and the questions raised in each of these over the four generations has resulted in the current space. This space is much less focused than it was in 1992 and now encompasses a multitude of possibilities and their combinations. This is a difficult space to navigate for most professionals in the field of sustainable mobility, let alone those outside the field. Sustainable mobility is still needed now, as it was in 1992, but it is much more needed as progress has been limited, partly due to the more holistic understanding of the problem being a relatively recent development (Table 1), and partly because the demand for transport has continued to increase, certainly by air and until relatively recently by car.

So, how does one bridge this gap between this large space of possibilities and its achievement? The search for traditional modelling approaches may be limited and limiting, as there will always be difficulties with data, with the complexity of the interactions, with the time dimension, with the existing inertia and lock-in in the system, with the vagaries of behaviour, with the lack of sufficient funding, and with the political difficulties of clear and consistent action when it comes to achieving sustainable mobility. It is not just the technical issues that present problems, but also the means by which the different options can be debated with and accepted by the many interested parties. Sustainable mobility is something that everybody has a view on. Considerable effort is needed to find appropriate means to communicate alternatives to businesses and the public, as there must be an appreciation and acceptance of the measures being proposed if the outcomes are to match up with expectations and if the prime objective of facilitating a sustainable mobility system in the future is to be achieved.

Achieving sustainable mobility is probably the most challenging task of the plethora of tasks pertaining to the wider challenge of achieving sustainable development. We know that we are in an unsustainable state and on an unsustainable path. We know fairly well what we need to do and we have sufficient knowledge about how to do it and who that should take the lead. Perhaps what we are lacking is stories-or sustainable mobility narratives—that we can believe in. History has shown that major changes are results of narratives we believe in, such as promoting individual freedom, fighting for democracy, abolishing slavery and fighting for woman liberation. As we are about to enter a fifth generation of sustainable mobility studies, we need to find those narratives and make actors-government, firms and the public-believe in them. Such narratives must provide easily accessible stories concerning how sustainable mobility systems might look in the future.

Author Contributions: E.H. conceived and presented the idea, initial theory and analysis. E.H., G.G. and D.B. discussed and developed the theories and analysis, and all contributed to the final manuscript.

Funding: This research received no external funding.

Conflicts of Interest: There are no conflict of interest.

\section{References}

1. European Commission. Green Paper on the Impact of Transport on the Environment. A Community Strategy for 'Sustainable Mobility', COM (92) 46 Final; Commission of the European Communities: Brussels, Belgium, 1992.

2. The World Commission on Environment and Development. Our Common Future; Oxford University Press: Oxford, UK, 1987. 
3. United Nations. Transforming Our World: The 2030 Agenda for Sustainable Development. Resolution Adopted by the General Assembly on 25 September 2015, A/RES/70/1; United Nations General Assembly: New York, NY, USA, 2015.

4. O'Riordan, T. The Politics of Sustainability. In Sustainable Environmental Management: Principles and Practice; Turner, K., Ed.; Belhaven: London, UK, 1988; pp. 29-50.

5. Shaker, R.R. The spatial distribution of development in Europe and its underlying sustainability correlations. Appl. Geogr. 2015, 63, 304-314. [CrossRef]

6. Holden, E. Achieving Sustainable Mobility: Everyday and Leisure-Time Travel in the EU; Ashgate: Aldeshot, UK, 2007.

7. Black, W.R. Transportation: A Geographical Analysis; Guilford Press: London, UK, 2003.

8. Sager, T.Ø. Freedom as mobility: Implications of the distinction between actual and potential travelling. Mobilities 2006, 1, 465-488. [CrossRef]

9. Holden, E.; Linnerud, K.; Banister, D.; Schwanitz, V.; Wierling, A. The Imperatives of Sustainable Development: Needs, Equity, Limits; Routledge: Abingdon, UK, 2017.

10. Holden, E.; Linnerud, K.; Banister, D. Sustainable Passenger Transport: Back to Brundtland. Transp. Res. Part A Policy Pract. 2013, 54, 67-77. [CrossRef]

11. International Energy Agency. Transport, Energy and $\mathrm{CO}_{2}$ : Moving towards Sustainability; International Energy Agency: Paris, France, 2009.

12. Holden, E.; Linnerud, K. The Future of Sustainable Passenger Transport. Note Commissioned by Directorate General for Internal Policies, Policy Department B: Structural and Cohesion Policies; European Parliament's Committee on Transport and Tourism: Brussels, Belgium, 2009.

13. Statistics Norway. Domestic Transport Performance. 2019. Available online: https://www.ssb.no/en/ statbank/table/03982 (accessed on 28 February 2019).

14. European Environmental Agency. Passenger and Freight Transport Demand. 2018. Available online: https: / / www.eea.europa.eu/data-and-maps/indicators / passenger-and-freight-transport-demand/ assessment (accessed on 21 January 2019).

15. Organisation for Economic Co-operation and Development. Passenger Transport. 2019. Available online: https: / / data.oecd.org/transport/passenger-transport.htm (accessed on 21 January 2019).

16. Yeh, S.; Mishra, G.S.; Fulton, L.; Kyle, P.; McCollum, D.L.; Miller, J.; Cazzola, P.; Teter, J. Detailed assessment of global transport-energy models' structures and projections. Transp. Res. Part D Transp. Environ. 2017, 55, 294-309. [CrossRef]

17. United Nations. The Future We Want; United Nations: New York, NY, USA, 2013.

18. International Energy Agency. Share of Total Final Consumption (TFC) by Sector-World 2016. 2018. Available online: https: / / www.iea.org/statistics / ?country=WORLD\&year=2016\&category=Energyconsumption\& indicator $=$ TFCShareBySector $\&$ mode $=$ chart $\&$ dataTable $=$ BALANCES (accessed on 21 January 2019).

19. Organisation for Economic Co-Operation and Development. Global Material Resources Outlook to 2060. 2019. Available online: http:/ / www.oecd.org/environment/global-material-resources-outlook-to-20609789264307452-en.htm (accessed on 4 March 2019).

20. International Energy Agency. $\mathrm{CO}_{2}$ Emissions Statistics. 2019. Available online: https://www.iea.org/ statistics/co2emissions/ (accessed on 4 March 2019).

21. European Environmental Agency. Landscapes in Transition-An Account of 25 Years of Land Cover Change in Europe. 2017. Available online: https://www.eea.europa.eu/publications/landscapes-in-transition (accessed on 22 January 2019).

22. World Health Organization. Road Traffic Injuries. 2018. Available online: https://www.who.int/newsroom/fact-sheets/detail/road-traffic-injuries (accessed on 22 February 2019).

23. Root, A.; Schintler, L.; Button, K. Women and Travel: The Sustainability Implications of Changing Roles. In Social Change and Sustainable Transport; Black, W.R., Nijkamp, P., Eds.; Indiana University Press: Bloomington, IN, USA, 2002; pp. 149-156.

24. Rudinger, G. Mobility Behaviour of the Elderly: Its Impacts on the Future Road Traffic System. In Social Change and Sustainable Transport; Black, W.R., Nijkamp, P., Eds.; Indiana University Press: Bloomington, IN, USA, 2002; pp. 157-164. 
25. Tillberg, K. Residential Location and Daily Mobility Patterns: A Swedish Case Study of Households with Children. In Social Change and Sustainable Transport; Black, W.R., Nijkamp, P., Eds.; Indiana University Press: Bloomington, IN, USA, 2002; pp. 165-172.

26. Uteng, T.P. Mobility: Discourses from the non-western immigrant groups in Norway. Mobilities 2006, 1, 435-462. [CrossRef]

27. Banister, D. Unsustainable Transport; Routledge: London, UK, 2005.

28. Black, W.R. Sustainable Transportation: Problems and Solutions; Guilford Press: New York, NY, USA, 2010.

29. Castillo, H.; Pitfield, D.E. ELASTIC - A methodological framework for identifying and selecting sustainable transport indicators. Transp. Res. Part D Transp. Environ. 2010, 15, 179-188. [CrossRef]

30. Litman, T.; Burwell, D. Issues in sustainable transportation. Int. J. Glob. Environ. Issues 2006, 6, 331-347. [CrossRef]

31. Schiller, P.L.; Bruun, E.C.; Kenworthy, J.R. An Introduction to Sustainable Transportation: Policy, Planning, and Implementation; Earthscan: London, UK, 2010.

32. Berger, G.; Feindt, P.; Rubik, F.; Holden, E. Sustainable Mobility - Challenges for a Complex Transition. J. Environ. Policy Plan. 2014, 16, 303-320. [CrossRef]

33. Braun, V.; Clarke, V. Using thematic analysis in psychology. Qual. Res. Psychol. 2006, 3, 77-101. [CrossRef]

34. Maguire, M.; Delahunt, B. Doing a Thematic Analysis: A Practical, Step-by-Step. Guide for Learning and Teaching Scholars. Irel. J. Teach. Learn. High. Educ. 2017, 8, 3351-33514.

35. Adams, J. Towards a sustainable Transport Policy. In Travel Sickness: The Need for a Sustainable Transport Policy for Britain; Roberts, J., Ed.; Lawrence \& Wishart: London, UK, 1992.

36. Banister, D.; Akerman, J.; Stead, D.; Nijkamp, P.; Dreborg, K.; Steen, P. European Transport Policy and Sustainable Mobility; Spon Press: London, UK, 2000.

37. Goodwin, P.; Parkhurst, G.P.; Stokes, G. Modifying Our Volume of Traffic: The Primary Route to Sustainable Transport; University of Oxford-Transport Studies Unit: Oxford, UK, 1992.

38. Masser, I.; Svidén, O.; Wegener, M. From Growth to Equity and Sustainability: Paradigm Shift in Transport Planning? Transp. Plan. Technol. 1992, 17, 232-247.

39. Whitelegg, J. Transport for a Sustainable Future. The Case for Europe; Wiley: London, UK, 1993.

40. Banister, D.; Button, K. (Eds.) Transport, the Environment and Sustainable Development; E \& FN Spon: London, UK, 1993.

41. Commission of the European Communities. The Future Development of the Common Transport Policy-A Global Approach to the Construction of a Community Framework for Sustainable Mobility, Bulletin of the European Communities, Supplement 3/93; Commission of the European Communities: Brussels, Belgium, 1993.

42. Høyer, K.G. Sustainable Mobility-The Concept and Its Implications. Ph.D. Thesis, Western Norway Research Institute, Sogndal, Norway, 2000.

43. Commission of the European Communities. The Common Transport Policy-Sustainable Mobility: Perspectives for the Future. COM (98) 716 Final; Commission of the European Communities: Brussels, Belgium, 1998.

44. Commission of the European Communities. White Paper. European Transport Policy for 2010: Time to Decide, COM (2001) 370 Final; Commission of the European Communities: Brussels, Belgium, 2001.

45. World Bank. Sustainable Transport: Priorities for Policy Reform; World Bank: Washington, DC, USA, 1996.

46. Organisation for Economic Co-operation and Development. Environmentally Sustainable Transport, Futures, Strategies and Best Practices Synthesis Report of the OECD Project on Environmentally Sustainable Transport EST, Presented on Occasion of the International EST! Conference 4 to 6 October in Vienna, Austria; Organisation for Economic Co-Operation and Development: Paris, France, 2000.

47. Organisation for Economic Co-operation and Development. Towards Sustainable Household Consumption? Trends and Policies in OECD Countries; Organisation for Economic Co-Operation and Development: Paris, France, 2002.

48. Gilbert, R. Social Implications of Sustainable Transport. In Social Change and Sustainable Transport; Black, W.R., Nijkamp, P., Eds.; Indiana University Press: Bloomington, IN, USA, 2002; pp. 63-70.

49. World Business Council for Sustainable Development. Mobility 2030: Meeting the Challenges to Sustainability, The Sustainable Mobility Project, Full Report 2004; World Business Council for Sustainable Development: Geneva, Switzerland, 2004.

50. Whitelegg, J. Critical Mass; Pluto Press: London, UK, 1997. 
51. Haq, G. Towards Sustainable Transport Planning: A Comparison between Britain and The Netherlands; Avebury: Aldershot, UK, 1997.

52. Tengström, E. Towards Environmental Sustainability? A Comparative Study of Danish, Dutch and Swedish Transport Policies in a European context; Ashgate: Aldershot, UK, 1999.

53. Black, W.R.; Nijkamp, P. Introduction: Pathways to Sustainable Transport and Basic Themes. In Social Change and Sustainable Transport; Black, W.R., Nijkamp, P., Eds.; Indiana University Press: Bloomington, IN, USA, 2002; pp. xi-xiii.

54. Geenhuizen, M. von et al. Social Change and Sustainable Transport: A Manifesto on Transatlantic Research Opportunities. In Social Change and Sustainable Transport; Black, W.R., Nijkamp, P., Eds.; Indiana University Press: Bloomington, IN, USA, 2002; pp. 3-16.

55. Wachs, M. Social Trends and Research Needs in Transport and Environmental Planning. In Social Change and Sustainable Transport; Black, W.R., Nijkamp, P., Eds.; Indiana University Press: Bloomington, IN, USA, 2002; pp. 17-26.

56. Janelle, D.G.; Beuthe, M. Globalization and Transportation: Contradictions and Challenges. In Social Change and Sustainable Transport; Black, W.R., Nijkamp, P., Eds.; Indiana University Press: Bloomington, IN, USA, 2002; pp. 49-54.

57. Rietveld, P.; Stough, R.R. Barriers to Sustainable Transport. Institutions, Regulations and Sustainability; Spon Press: London, UK, 2005.

58. Williamson, O.E. Institutions and Economic Organizations-The Governance Perspective; World Bank: Washington, DC, USA, 1994.

59. Gorham, R. Car Dependence as a Social Problem: A Critical Essay on the Existing Literature and Future Needs. In Social Change and Sustainable Transport; Black, W.R., Nijkamp, P., Eds.; Indiana University Press: Bloomington, IN, USA, 2002; pp. 107-116.

60. Sandqvist, K. Growing Up with and Without a Family car. In Social Change and Sustainable Transport; Black, W.R., Nijkamp, P., Eds.; Indiana University Press: Bloomington, IN, USA, 2002; pp. 117-124.

61. Gatersleben, B.; Uzzell, D. Sustainable Transport and Quality of Life: A Psychological Analysis. In Social Change and Sustainable Transport; Black, W.R., Nijkamp, P., Eds.; Indiana University Press: Bloomington, IN, USA, 2002; pp. 35-140.

62. Feitelson, E. Introducing Environmentally Equity Concerns into the Discourse on Sustainable Transport: A Research Agenda. In Social Change and Sustainable Transport; Black, W.R., Nijkamp, P., Eds.; Indiana University Press: Bloomington, IN, USA, 2002; pp. 141-148.

63. Salomon, I.; Mokhtarian, P.L. Driven to Travel: The identification of Mobility-Inclined Market Segments. In Social Change and Sustainable Transport; Black, W.R., Nijkamp, P., Eds.; Indiana University Press: Bloomington, IN, USA, 2002; pp. 173-180.

64. Anable, J. Picnics, Pets, and Pleasant Places: The Distinguishing Characteristics of Leisure Travel Demand. In Social Change and Sustainable Transport; Black, W.R., Nijkamp, P., Eds.; Indiana University Press: Bloomington, IN, USA, 2002; pp. 181-190.

65. Edinger, R.; Kaul, S. Sustainable Mobility: Renewable Energies for Powering Fuel Cell Vehicle; Praeger: London, UK, 2003.

66. Åkerman, J. Sustainable air transport-On track in 2050. Transp. Res. Part D 2005, 10, 111-126. [CrossRef]

67. European Commission. White paper. Roadmap to a Single European Transport Area-Towards a competitive and Resource Efficient Transport System. COM (2011) 144 Final; Commission of the European Communities: Brussels, Belgium, 2011.

68. European Commission. Europe on the Move-An Agenda for a Socially Fair Transition towards Clean, Competitive and Connected Mobility for All, COM/2017/0283 Final; Commission of the European Communities: Brussel, Belgium, 2017.

69. Guinee, J.B.; Heijungs, R.; Huppes, G.; Zamangni, A.; Masoni, P.; Buonamici, R.; Ekval, T.; Rydberg, T. Life Cycle Assessment: Past, Present, and Future. Environ. Sci. Technol. 2011, 45, 90-96. [CrossRef]

70. Vilhelmson, B. Vår Dagliga Rørlighet. Om Resandes Utveckling, Førdelning och Gränser [Our Daily Mobility. On the Development, Distribution and Limits of Travelling] TFB Report 16; The Swedish Transport Board: Stockholm, Sweden, 1990.

71. Santos, G. Sustainability and Shared Mobility Models. Sustainability 2018, 10, 3194. [CrossRef] 
72. Machado, C.A.S.; De Salles Hue, N.P.M.; Berssaneti, F.T.; Quintanilha, J.A. An Overview of Shared Mobility. Sustainability 2018, 10, 4342. [CrossRef]

73. Rosenzweig, J.; Bartl, M. A Review and Analysis of Literature on Autonomous Driving. E-J. Mak. Innov. 2015, 1-13.

74. Marletto, G. Who will drive the transition to self-driving? A socio-technical analysis of the future impact of automated vehicles. Technol. Forecast. Soc. Chang. 2018, in press. [CrossRef]

75. Hulse, L.M.; Xie, H.; Galea, E.R. Perceptions of autonomous vehicles: Relationships with road users, risk, gender and age. Saf. Sci. 2018, 102,1-13. [CrossRef]

76. Straub, E.R.; Schaefer, K.E. It takes two to Tango: Automated vehicles and human beings do the dance of driving-Four social considerations for policy. Transp. Res. Part A Policy Pract. 2018, in press. [CrossRef]

77. Figenbaum, E.; Assum, T.; Kolbenstvedt, M. Electromobility in Norway: Experiences and Opportunities. Res. Transp. Econ. 2015, 50, 29-38. [CrossRef]

78. Castelli, M.; Beretta, J. Development of electromobility in France: Causes, facts and figures. World Electr. Veh. J. 2016, 8, 772. [CrossRef]

79. Martin, B.R. The evolution of science policy and innovation studies. Res. Policy 2012, 41, 1219-1239. [CrossRef]

80. Markard, J.; Raven, R.; Truffer, B. Sustainability Transitions: An emerging field of research and its prospects. Res. Policy 2012, 41, 955-967. [CrossRef]

81. Geels, F. A socio-technical analysis of low-carbon transitions: Introducing the multi-level perspective into transport studies. J. Transp. Geogr. 2012, 24, 471-482. [CrossRef]

82. Whitmarsh, L. How useful is the Multi-Level Perspective for transport and sustainability research? J. Transp. Geogr. 2012, 24, 483-487. [CrossRef]

83. Klitkou, A.; Bolwig, S.; Hansen, T.; Wessberg, N. The role of lock-in mechanisms in transition processes: The case of energy for road transport. Environ. Innov. Soc. Transit. 2015, 16, 22-37. [CrossRef]

84. Berggren, C.; Magnusson, T.; Sushandoyo, D. Transition pathways revisited: Established firms as multi-level actors in the heavy vehicle industry. Res. Policy 2015, 44, 1017-1028. [CrossRef]

85. Dijk, M.; Wells, P.; Kemp, R. Will the momentum of the electric car last? Testing an hypothesis on disruptive innovation. Technol. Forecast. Soc. Chang. 2016, 105, 77-88. [CrossRef]

86. Nikulina, V.; Simon, D.; Ny, H.; Baumann, H. Context-adapted urban planning for rapid transitioning of personal mobility towards sustainability: A systematic literature review. Sustainability 2019, 11, 1007. [CrossRef]

87. Kern, F.; Smith, A. Restructuring energy systems for sustainability? Energy transition policy in the Netherlands. Energy Policy 2008, 36, 4093-4103. [CrossRef]

88. Kemp, R.; Schot, J.; Hoogma, R. Regime shifts to sustainability through processes of niche formation: The approach of strategic niche management. Technol. Anal. Strateg. Manag. 1998, 10, 175-195. [CrossRef]

89. Geels, F.; Schot, J. Typology of sociotechnical transition pathways. Res. Policy 2007, 3, 399-417. [CrossRef]

90. Bergek, A.; Jacobsson, S.; Carlsson, B.; Lindmark, S.; Rickne, A. Analyzing the functional dynamics of technological innovation systems: A scheme of analysis. Res. Policy 2008, 37, 407-429. [CrossRef]

91. Brand, C.; Hunt, A. Health Costs of Air Pollution from Cars and Vans, University of Oxford, Transport Studies Unit, School of Geography and the Environment, Report for Global Action Plan. 2018. Available online: https: / / www.cleanairday.org.uk/Handlers/Download.ashx?IDMF=7eb71636-7d06-49cfbb3e-76f105e2c631 (accessed on 18 February 2019).

92. Banister, D. Inequality in Transport; Alexandrine Press: Oxford, UK, 2018.

(C) 2019 by the authors. Licensee MDPI, Basel, Switzerland. This article is an open access article distributed under the terms and conditions of the Creative Commons Attribution (CC BY) license (http:// creativecommons.org/licenses/by/4.0/). 